\title{
Security Issues and Refugees: Dilemmas, Crises, and Debates
}

\section{Frances T. Pilch}

\begin{abstract}
Complex emergencies involving refugees often involve dilemmas concerning security issues. Questions concerning the neutrality and demilitarization of refugee camps, the protection of aid and humanitarian workers, and law enforcement within the camps themselves continually arise. These issues are exacerbated when refugee flows occur in highly unstable areas sometimes characterized as "failed states." While debate has been stimulated by reflections on the Great Lakes crisis and has fostered creative thinking about security options, definitive plans for the support of humanitarian operations has not yet materialized. The burden placed upon UNHCR to operate in problematical situations leads inevitably to ad hoc policy arrangements, which need to be replaced with concrete operational contingency planning, possibly involving standby forces dedicated to the support of humanitarian operations.
\end{abstract}

\section{Résumé}

Les situations $d^{\prime}$ urgences complexes où des réfugiés sont concernés, présentent souvent des dilemmes sur des questions de sécurité. Des problèmes surgissent continuellement, liés à la neutralité et la démilitarisation des camps de réfugiés, la protection des travailleurs d'aide humanitaire, ainsi que le maintien de l'ordre à l'intérieur-mêmedes camps. Ces problèmes se trouvent exacerbés lorsque les flux de réfugiés surviennent dans des régions à haute instabilité, qui sont même parfois appelées « états en faillite ». Alors que le débat s'est trouvé stimulé par des réflexions sur la crise des Grands Lacs et a encouragé la créativité dans la re-

Ph.D., Department of Political Science, United States Air Force Academy. E-Mail: Frances.Pilch@usafa.af.mil Tel: (719)3338014.Presented at the International Studies Association Annual Meeting.Los Angeles, March 2000Security Issues and Refugees: Dilemmas, Crises, and Debates. cherche d'options possibles en matière de sécurité, desplans définitifs sur la façon de soutenir les opérations humanitaires $n^{\prime}$ ont toujours pas vu le jour. Le fardeau imposé au HCR d'opérer dàns des situations problématiques mène immanquablement à l'adoption de solutions et de politiques improvisées. Il importe de les remplacer par des plans d'urgence concrets, comportant peut-être des troupes en état d'alerte et réservées uniquement au soutien des opérations humanitaires

\section{Introduction}

In recent years, refugee flows have reached staggering proportions. The United Nations High Commissioner for Refugees (UNHCR) estimates that 22.7 million people in over 140 countries fall under its concern. ${ }^{1}$ In addition, the kinds of conflicts that are producing refugees are different from those that fostered the original legal instruments governing the refugee regime. In contrast to the international conflicts of the first half of the Twentieth Century, the last fifty years havebeen witness primarily to internal conflicts - many of which have targeted civilian populations. The instability and violence that have accompanied these kinds of conflicts, in which particular ethnic groups or minorities have often been especially at risk, have led to massive refugee flows across international borders. In addition, internally displaced populations have become an issue of great concern to $\mathrm{UNHCR}^{2}$

When massive flows of refugees have crossed national boundaries, they have often entered regions that have few resources and weak governmental infrastructure. In some cases, host states themselves have been in a state of virtual collapse and the regions into which refugees have relocated have been in a state of chaos or even civil war. These kinds of situations have posed enormous problems for UNHCR. Many questions have arisen: how to establish and protect access to refugees, how to protect humanitarian aid workers, how to maintain neutrality in situations involving conflict and how to prevent refugee camps from becoming bases for armed militant groups. Aspects of these issues are relevant in refugee situations in West Timor, Kosovo, Tanzania, Kenya, the South Kivu Province in the Democratic Republic of the Congo(DRC) and in the current controversy over humanitarian aid in Sudan. From these challenges has arisen genuine debate over the best way in which UNHCR can accomplish its mandate given these highly volatile and unstable situations. One of the central questions being asked is, "What is the nexus between security and humanitarian aid to refugees?" Who is responsible for security arrangements and what has been the experience of UNHCR with regard to these issues? What are the possible policies regarding the physical security of refugee populations? These issues have framed a serious debate over the role of UNHCR in the contemporary world of internal and international conflicts.

\section{Refugees and the Failed State ${ }^{3}$}

Host states are generally considered to be responsible for the security of refugee populations. UNHCR generally is invited by the host government to administer relief to these populations, and is present with the consent of a government. The Refugee Convention of 1951 and its 1967 Protocol require signatories to provide refugees with the same minimum standards given comparable populations within their borders. In theory, it is the responsibility of the host state to provide for the physical security of refugees.

In fact, however, refugee flows have often entered areas of minimal infra-

Refuge, Vol. 19, No. 1 (July 2000) 
structure and control by a central authority. In 1994, more than 2 million refugees exited Rwandan. Large populations entered Tanzania and the eastern provinces of the DRC, formerly Zaire. In the case of Zaire, the situation was especially chaotic. Zaire's population of 40 million had been governed since the $1960^{\prime}$ s by Mobuto Sese Seko, who had literally robbed the country of billions of dollars. Zaire was in economic shambles: $85 \%$ of its roads at independence had, by 1994 disintegrated into bush. AIDS was rampant, and governmental administration was nonexistent or corrupt. ${ }^{4}$ Zaire was an example of "the new African spectre of stateless countries," which was also seen in Somalia, Liberia and Sierra Leone. ${ }^{5}$

This phenomenon of the "failed state" poses substantial challenges for institutions seeking to provide humanitarian relief. Failed states are "invariably the product of a collapse of the power structures providing political support for law and order, a process generally triggered and accompanied by 'anarchic' forms of internalviolence." ${ }^{6}$ Former SecretaryGeneral of the United Nations, Boutros Boutros-Ghali, described the situation as follows:

A feature of such conflicts is the collapse of state institutions, especially the police and judiciary, with resulting paralysis of governance, a breakdown of law and order and general banditry and chaos. Not only are the functions of government suspended, but its assets are destroyed or looted and experienced officials are killed or flee the country. This is rarely the case in inter-state wars. ${ }^{7}$

The basic instruments of international law regarding refugees, the 1951 Convention Relating to the Status of Refugees and its 1967 Protocol, utilize a definition of refugee that has in fact been broadened in practice. Originally written in response to the massive relocations after World War II, the 1951 Convention defines a refugee as any person who

owing to a well-founded fear of being persecuted for reasons of race, reli- gion, nationality, membership of a particular social group or political opinion, is outside the country of his nationality and is unable or, owing to such fear, is unwilling to avail himself of the protection of that country or to return to it. ${ }^{8}$

The 1967 Protocol removed the date and geographical limitations of the original convention, making it a truly universal instrument. To date there are more than 137 states party to one or both of these legal instruments.

The original definition of refugee has in fact been broadened however, The Organization of African Unity Convention (OAU) Governing the Specific Aspects of Refugee Problems in Africa, adopted in 1969, is the most important of several regional instruments. It expands the definition of refugee to include

every person who, owing to external aggression, occupation, foreign domination or events seriously disturbing public order in either part or the whole of his country of origin or nationality, is compelled to leave his place of habitual residence in order to seek refuge in another place outside his country of origin or nationality. ${ }^{9}$

The 1951 Geneva Refugee Convention talked about refugees in terms of individual persecution. The OAU Convention greatly broadened the definition of refugee, to include those people fleeing external aggression, occupation, foreign domination, or serious public disorder. Refugee status under the OAU Convention could be granted to groups as well as individuals. In addition, this convention was the first legal document to include the principle of voluntary repatriation. The OAU convention was designed in the post-decolonization era, when many important African leaders aspired to Pan-Africanism. African states were encouraged to open theirborders to their brothers and sisters from other parts of the continent; and indeed, many states were then and some still are, welcoming refugees.

In the early 1970's, optimism prevailed. Most African leaders viewed refugee problems as transitory. Refugees themselves numbered about one million and there was significant regional cooperation in dealing with refugees. However the sheer numbers of refugees, 7.2 million in 1999, combined with the lack of economic development in many African states and theincreasing numbers of internal crises and conflicts, have caused a significant change in the willingness and capacities of many African states to host massive numbers of refugees. The emphasis turned to voluntary repatriation in the 1980s, and this has been the primary objective of most refugee projects.

The problem is no longer considered transitory but virtually intractable. And every aspect of the 'African refugee crisis' has changed dramatically. The main source of refugees is no longer wars of independence, but more often brutal civil and guerilla conflicts. Humanitarian refugee situations have become politicized and militarized beyond recognition. Refugees are rarely welcomed as guests these days and states are increasingly following the lead of the regions of the world in closing their doors. ${ }^{10}$

The 1950 Statute of UNHCR specifies the mandate of UNHCR, which is the protection and assistance of refugees. Its functions include providing international protection and seeking permanent solutions for the problems of refugees. According to Chapter I, General Provisions of the Statute, "The work of the High Commissioner shall be of an entirely nonpolitical character; it shall be humanitarian and social..."11 The High Commissioner is charged with providing for the protection of refugees by "(p)romoting through special agreements with Governments the execution of any measure calculated to improve the situation of refugees and to reduce the number requiring protection." 12

\section{The Case of Eastern Zaire}

The politicization and militarization of refugees was first seen on a large scale in the Horn of Africa in the 
early 1990s, when Ethiopian refugees participated in large scale assaults on humanitarian relief supplies and on the Somali population. The crisis in Eastern Zaire, however, following the genocide in Rwanda in 1994, brought these problems into high relief. The Great Lakes crisis was truly a watershed in refugee issues and has led to serious assessments of refugee policies. ${ }^{13}$

Among the most serious dilemmas facing the aid agencies was the question of separating militarized elements from true refugee populations. In 1994, for example, the dilemma reached a peak with the acknowledgement that armed elements were not only prevalent within the camps, but in some cases actually controlled them. Nevertheless, UNHCR continued to try to feed the refugee populations and tried to help the innocent. The High Commissioner, Sadako Ogata has stressed the difference between humanitarian aid and military or policing activities, which, she has said, is the purview of the Security Council of the United Nations. ${ }^{14}$ Others have suggested that in a complex crisis such as that of the Great Lakes, in which armed elements and guerrilla fighters are harbored in camps, once an immediate crisis is addressed, the aid agency should simply pull out. These critics have argued that if the local host government is unable or willing to provide necessary security arrangements and if the Security Council or a regional institution is also unable or unwilling to ensure the security of large refugee populations, humanitarian agencies should not be put in the position of operating in an insecure environment or trying to accomplish objectives which are not part of their mandates. Another significant change apparent during and after the Great Lakes Crisis was the new danger to aid workers. A total of $36 \mathrm{UNHCR}$ staff and workers were killed or lost during the crisis. ${ }^{15}$

It was very clear in Eastern Zaire that the camps were occupied by both innocent civilians and armed ele- ments from the former Rwandan army and the Interahamwe. These armed elements intimidated the refugee populations. Many of the refugees themselves had been forced to leave Rwanda and sometimes even killed when they wanted to return. If these factions did not live within the camps, they lived immediately outside of them. President Nyerere of Tanzania commented on this situation:

I was involved in the diplomatic work to get the international community to take the necessary action to separate the armed groups from the genuine refugees. The international community failed in that. They talked, talked, and talked. And eventually Rwanda decided to do a bit of self help (in helping destroy the camps). And today when we are talking of foreign armies in Congo, people forget about that of the other army - the Interahamwe - which is still there. ${ }^{16}$

A debate raged concerning the problem of functioning in this atmosphere of the militarization and politicization of refugee camps. In an Op Ed piece, Alain Destexhe, then Secretary-General of Médecins Sans Frontières, announced that his organization would withdraw from Rwandan refugee camps in Zaire and Tanzania, because aid to refugees was, in effect, supporting killers. ${ }^{17}$ He maintained that the only hope of breaking the grip of the armed elements would be an international force to police the camps, requested by - many aid agencies. However, a UN official announced that a plan to send an international force to restore order to Rwandan refugee camps in Eastern Zaire was to be shelved for lack of funds and troops. ${ }^{18}$ Destexhe noted that " $(t)$ he camps have turned into prisons. International aid is the key to their (armed elements) efforts to resume the war. Food represents power." ${ }^{19}$ A UNHCR spokesman responded that the situation was indeed perilous, but that UNHCR could not abandon the innocent. $^{20}$

The problems of "safe havens," also arose in reference to the post-
Rwandan genocide refugee crisis. Operation Turquoise, $a$ "safe humanitarian zone" created by the French in southwest Rwanda, for Hutus fleeing from the advancing Rwandan Patriotic Front, has generated much international criticism. This unilateral French initiative, endorsed by the Security Council, appeared to provide protection to those who had instigated the genocide. "Armed extremist Hutu militia members operated openly in the zone, continuing to kill Tutsis living there and intimidating those Hutus living in camps who wanted to go home." 21 In the end, after France had turned over the operation to UNAMIR, violent confrontations between RPA troops and Hutu extremists took place in which perhaps thousands were killed.

One of the operating principles of the agreements between governments and UNHCR is that camps be located away from sensitive borders and that they remain civilian, humanitarian, and neutral. The OAU Refugee Convention also stipulates these provisions. Clearly, the failure of the governments of Zaire and to a lesser extent Tanzania to comply with these provisions, exacerbated the crisis. UNHCR has maintained that the need to move the camps, which was essentially a treaty obligation in Zaire and Tanzania, was ignored. Because the camps were not moved, it became almost impossible to separate civilian refugees from agents of genocide. At first, militia wore uniforms and brandished arms openly. Later, one aid worker notes, uniforms were taken off and arms were hidden, when it became apparent that it was necessary to do that to obtain food and other supplies. In fact, this expert notes that it would have been extremely difficult to distinguish between innocent civilians, the FAR and the extremists. "It was impossible to separate them - they were husbands, sons, and even daughters." 22

One expert has commented that "in such a massive and difficult crisis, the 
basic protection concerns are an early review of the refugees' profile; the separating out of fighters and killers; and the location of camps away from sensitiveborders." ${ }^{23}$ He notes the critical nature of support from key regional and international governments, which in the case of Zaire, was not forthcoming.

After other aid agencies threatened to pull out of the region, an ad hoc arrangement was developed. An elite Zairian force, Contingent Zaïrois pour la Sécurité dans les Camps, under the auspices of the UN, began what were essentially peacekeeping operations in refugee camps where former militias had been perpetrating violence and intimidation. A multinational team oversaw this contingent.

At the time, apparently, many other options were considered, including the use of contracted security forces, or security firms. Contracted "mercenaries," or "security for hire," have been used in some instances in Africa. The Sierra Leone Secretary of Mines allegedly employed mercenaries at one time - many of them drawn from the former South African army. ${ }^{24}$ However, the use of contracted private security guards was seen to have substantial drawbacks, not the least of which was prohibitive cost. ${ }^{25}$

This ad hoc arrangement utilizing the Zairian contingent was the first in the history of UNHCR, in which a nation's troops were used as peacekeepers on their own soil. Their orders were not to separate armed elements from civilians or perform disarmament itself, but rather only to maintain order in aid distribution. The UN would spend $\$ 1.3$ million to pay for their clothes and equipment. ${ }^{26}$

UNHCR also paid the salaries of the Zairians during the crisis. The contingent itself was drawn from Mobutu's Presidential Guard, and was considered an "elite force," that was more a "gendarmerie" than a military unit. However, when the camps were attacked by Tutsi rebels in 1996, most of the Zairian contingent fled. Some Zairians were implicated in improper conduct (some apparently went away with vehicles, etc.), but some tried to "stick it out." 27

At the end of 1995, the situation in Eastern Zaire was growing even more precarious. Tutsis, who had lived in the region for 200 years, were often considered foreigners and were harassed by provincial Zairian authorities. Hutu refugees in the area were accused of encouraging Zairian Hutu to attack their neighbours.

A large population of predominantly Hutu refugees from Burundi was also present in eastern Zaire. In late 1996 many were forced back to Burundi by Tutsi-led Zairian armed groups and handed over to Burundi government forces at the border. Hundreds of adult men are believed to have been executed by the Burundi security forces near the border or in the capital, Bujumbura. ${ }^{28}$

In late 1995, Tutsi rebels began to challenge the Zairian army; and the Zairian government accused the Rwandan government of supporting the insurgency. Meanwhile, incursions by former FAR elements across the border into Rwanda were occurring with greater frequency. In November, 1996, Goma in Zaire fell to the rebels, undoubtedly supported by the Rwandan army. The UN evacuated its relief workers and thousands of refugees scattered, many into the interior forests of Zaire. ${ }^{29}$ The rebel insurgents, with the aid of the Rwandan army, eventually made their way to Kinshasa, where they met little resistance in assuming control of the government, deposing Mobuto Sese Seko, who died shortly thereafter in a neighbouring state, from prostate cancer.

During this time period, the international community, responding to the chaos in the region and hearing reports that hundreds of thousands of refugees were at serious risk, began to consider military intervention. Canada volunteered to lead an international force into Eastern Zaire. The plan for between 10,000 and 15,000 ground troops from approximately a dozen nations was reluctantly endorsed by other members of the Secu- rity Council, including the US, which sent a team of 40 military observers to assess the situation. The mission of the force would have been to secure the airfield at Goma and establish a 3 mile-wide corridor from Goma to Rwanda. This would have been a combination of an effort to secure access for humanitarian airlift of supplies and also to encourage Rwandan repatriation. ${ }^{30}$

When the Tutsis routed the camps in November 1996, however, huge numbers of refugees began an unprecedented massive return to Rwanda. When governments and aid groups met in Stuttgart, enthusiasm for the military option had declined. Laurent Kabila, who had been installed as President of the DRC, proclaimed that "no foreign force" would be permitted on DRC's territory. ${ }^{31}$ By December, 1996, the idea of a UN emergency operation had essentially been ruled out.

The Great Lakes crisis, as it came to be called, focused international attention on the dilemmas faced by UNHCR in coping with massive influxes of refugees into highly unstable areas or into states with little or no administrative capacities. Zaire had little infrastructure or capacity to provide security for the camps. The massive refugee flow upset an already precarious ethnic balance and required resources which the region simply did not have. Ad hoc arrangements became necessary as UNHCR negotiated with local authorities. Eventually, under pressure from many aid groups, the Zairian contingent was underwritten by the UN. Neither the regional organizations nor the international community as a whole was willing to provide the resources and troops that would have been necessary to secure the camps and ensure the delivery of supplies. The consequences of this inability to provide security are well-known. The ramifications of the post-1994 crisis have been grave - a state in further collapse in which 22 different entities are participating in what has come to be called Africa's First World War, the loss of thousands 
of lives of refugees in the jungles of Central Zaire and a refugee crisis that has spread from the borders of Rwanda all the way into Congo Brazzaville.

\section{A Contrasting Case: Security and Refugees in Northern Iraq ${ }^{32}$}

In 1991, following the conclusion of the Gulf War, a crisis involving the Kurds located in the northern area of Iraq began to unfold. Encouraged by remarks by President Bush and possibly believing that Iraqi forces had been substantially undermined during the war, various Kurdish elements in this area mounted a revolt. Republican guards, however, quickly entered the area, driving thousands of Kurds into the harsh mountains of Northern Iraq and Southern Turkey. Turkey, unwilling to receive massive influxes of Kurds, reinforced its borders, even, in some instances, firing on Kurdish civilians. In spite of reports that there were more than 450,000 refugees in the mountains, and that the death rate was more than 2000 refugees per day, the international community seemed at first to be immobilized. The United States found itself in a diplomatic quandary-its NATOally, Turkey, refused to receive the refugees. Yet clearly, the situation, from a humanitarian perspective, was becoming critical.

Secretary of State, James Baker, surveyed the situation from the air and reported to President Bush on the severity of the problem. At the time, the borders between Turkey and Iraq were porous and ill defined, and the U.S. military was not allowed on the ground in the area. Nevertheless, flights into the area were conducted fairly frequently. The U.S. military began to plan contingency operations for a humanitarian operation, should the President order one. In fact, one Sunday, President Bush announced that the U.S. would begin an airdrop of supplies. In themeantime, Mme. Mitterand, wife of France's President Mitterand, had designed a "way point" policy, in which the military would secure way points on mountain passes to facilitate repatriation of the refugees. With this plan as a starting point, a coalition of NATOnations met in Ankara to discuss the difficulties of securing supplies for and repatriation of the Kurdish refugees. Having seen firsthand the extreme difficulty in airdropping of supplies into the area (weather conditions were dangerous and supplies often did not reach those for whom they were intended), Operation Provide Comfort was born. A "security zone" was created to bring the refugees out of the mountains, utilizing way points set up by the French. Turkey's permission was secured for the staging of the operation. A map was drawn following a natural ridgeline, and an area designated for humanitarian operations.

The Iraqi army was present in very small numbers in this area at that time. However, it was decided that Iraqi tanks and heavy artillery would not be permitted to enter. An army colonel was sent in a jeep with a white flag to speak with the Iraqi general in that area. The general was told that the coalition forces were coming across into this zone, not to occupy it, but to facilitate the return of the Kurds and to supply them with relief aid. The Iraqi general reported that the would relay the message. Subsequent to that, there was a tacit understanding that 'Operation Provide Comfort would proceed. The Iraqi military in the zone were not disarmed or harmed.

UN officials, including Mrs. Ogata, were briefed in Paris prior to the introduction of military force into the area. UNHCR had representation in the zone, and the operation was endorsed under Chapter VII of the UN Charter and Security Council Resolution 688. It called the suppression of the Kurds a threat to "international peace and security in the region," required Iraq to allow humanitarian relief into that area and demanded that Iraq cooperate with the Secretary-General to realize these goals. ${ }^{33}$

As a result, aircraft of Turkey, France, the United Kingdom and the United States began air operations from Incirlik Air Base in Turkey to enforce a "no-fly" zone. This zone was originally designed to ensure that relief could be provided to Kurds on the ground and that forces enforcing distribution of aid and securing return of the refugees would be protected. The demarcation line was the $36^{\text {th }}$ parallel, which to date still delineates the Northern No-Fly Zone in Iraq, which was not discontinued after the refugee crisis was over.

In contrast to the situation in Eastern Zaire, one finds in an analysis of the Kurdish refugee crisis a strong determination on the part of the NATO coalition, led by the United States, to provide security for a humanitarian operation. Because of perceived strategic interests in that area, not the least of which was a desire to prevent the destabilization of Turkey through a massive influx of Kurds and fueled by the "CNN effect," which highlighted the impending humanitarian disaster, the international community took a decisive action. This action was buttressed by legal arguments contained in the Security Council Resolutions. In many respects, this instance foreshadowed operations in Kosovo, in which there were strong and close ties between humanitarian and military operations. Mrs. Ogata noted these ties and also the relationship between political solutions and humanitarian action when she commented that " $(t) h e$ Gulf crisis was a major turning point for humanitarian and refugee work. It gave a new dimension not only to material assistance to victims of conflict and mass displacement, but also to the manner in which political action and humanitarian aid interact with each other." 34

\section{Recent Security Provisions in Refugee Operations: West Timor, Kenya, Tanzania, Sudan, and Thailand}

Issues concerning refugee safety, neutrality and location of camps and administration of aid in hostile environments continually arise. In Thailand, for example, the Bangkok government has asked UNHCR to expand its assistance to approximately 100,000 refugees from Myanmar who live in camps along a common border. Some of the refugees have been subject to 
armed attack and UNHCR has been asked tohelp move refugees away from sensitive border areas. ${ }^{35}$

In fact, Thailand represents one of the earliest examples of cooperation between national military forces and humanitarian refugee efforts. In the 1980 s, Vietnamese refugees, seeking to reach Thailand by boat, were often subjected to "pirates" in the South China Sea. The Thai Coast Guard, funded by UNHCR, mounted an antipiracy project to apprehend the hijackers. A liaison unit, equipped by UNHCR and made up of Thais, patrolled an area of the sea, providing some access for victims. In some instances, there were attempts to prosecute some of the pirates.

Currently, an interesting and innovative arrangement is taking place in Tanzania, in which UNHCR is providing material support to Tanzanian police units to help maintain law enforcement and security of camps. ${ }^{36}$ Incentives in the nature of financial backing of salaries, training and equipment to the police are provided. The refugees consist primarily of Burundians, fleeing the civil war in the DRC and Rwandans. The total refugee population is more than 800,000 . Tanzania, which had always been a model of the "welcoming state" for African refugees, had recently changed its open door policy.

In 1995, Tanzania closed its border to approximately 50,000 Rwandan and Burundian refugees. With the advent of a multi-party system, the end of Ujamaa, and a more open press, land became more highly prized and opposition to the "open door" policy more pronounced. The presence of armed elements in the refugee population from Rwanda in 1994 and the fears that the situation in Tanzania might degenerate to resemble that in Eastern Zaire, caused this major shift in Tanzanian policy. According to Tanzania's Deputy Home Affairs Minister, "Protecting and assisting refugees has brought new risks to national security, exacerbated tensions between states and caused extensive damage to the environ- ment." 37 In light of the overwhelming burden of refugee influxes on states that have limited resources, the new program to support dedicated Tanzanian police units in their efforts to provide security to refugee camp operations has been a welcome innovation, that is generally acknowledged as successful.

Some support has also been given from UNHCR to Kenya. UNHCR has experienced severe problems in the Dadaab camp, which borders Ethiopia and is not far from Uganda. There, banditry and unlawfulness have been rampant. Interclan rivalries have fuelled violence in the camps and among the refugee population, which is largely Somalian. Women have been the principal victims and UNHCR reported a disturbingly high incidence of rape, some perpetrated by fellow refugees. ${ }^{38} \mathrm{Be}-$ cause the local enforcement capacity of the Kenyan government wasjudged to be very weak, support was given to reinforce the police. In addition, there has been an attempt to provide support for the prosecution of rape cases in local courts. ${ }^{39}$ According to one UNHCR expert, refugee communities are often very large and involve typical law and order issues common to any large community - theft, rape, intimidation, and disorderly conduct. In many cases, the local judicial or law enforcement infrastructure is unable to cope with the new security problems generated within the camps. For example, jail space may be very limited, or the judicial structure weak or non-existent. ${ }^{40}$

Recent incidents in the civil war in Sudan have further highlighted the dilemmas facing humanitarian aid agencies concerning neutrality. In February 2000, the SPLA army, fighting for autonomy for the southern half of Sudan, demanded that relief agencies sign a "Memorandum of Understanding (MOU)" which would have the effect of recognizing the SPLA's jurisdiction over aid operations, including vehicles, evacuation and local hiring. At first, international aid agencies uniformly condemned this memorandum, which would have effectively denied the agencies the neutrality which they have long considered essential to their work. However, as the March 1 deadline approached, many groups decided to sign the MOU, fearing that if they withdrew from the area, the vulnerable population would suffer. The EU's humanitarian office has taken a hard line against the memorandum and has criticized those agencies and NGOs that have acceded to it. The US government, in contrast, has decided to support the individual choices of NGOs. This example is representative of the kinds of issues concerning neutrality facing the humanitarian relief organizations.

In October 1999, Mrs. Ogata commented on the problems of the displaced in East and West Timor. "Since the arrival of the InterFET multinational force, UNHCR has worked in East Timor as part of an inter-agency team in bringing protection and assistance to displaced people...A UNHCR emergency team is now in Kupang, but access to refugees continues to be difficult and sporadic...it is the protection and security situation that is of more serious concern. There are many reports of people having been forced by militias to leave East Timor. There are reports of people who may be forcibly kept, hostage-like, in West Timor." Mrs. Ogata continued by stressing that "the Indonesian government must provide all necessary security measure to secure both refugees and humanitarian agencies, maintain the civilian character of refugee sites and facilitate humanitarian activities." $\mathbf{4 1}$

\section{Debates Over Policy Alternatives}

Questions concerning security provisions involving refugees and humanitarian relief workers have become critical issues for debate. In 1998, Secretary-General Kofi Annan was directed by the Security Council to report on African conflict and the promotion of peace in the continent. Sections 53-55 of his report spoke directly to these issues. "The potential threat to African States posed by the movement of large 
numbers of refugees when they are mingled with combatants must be acknowledged. In the area of the Great Lakes, the movement of large numbers of Rwandan refugees into neighboring countries became a destabilizing factor for those countries, as well as for the new Government in Rwanda." 42

He recommended that refugee camps and settlements be kept free of any military presence or equipment, including arms and ammunition; that the neutrality and humanitarian character of the camps and settlements be scrupulously maintained; and that refugees be settled at a reasonable distance from any border, in camps of limited size. He noted that "some of the requirements relating to the protection of refugees and the support of States hosting large refugee populations are beyond the capacity of humanitarian providers. Many relate to matters of international peace and security for which the Security Council has primary responsibility." 43 In an important policy recommendation, the report concludes:

I therefore urge the establishment of an international mechanism to assist host government in maintaining the security and neutrality of refugee camps and settlements. Such a mechanism might encompass training, logistics, financial support, the provision of security personnel and the monitoring of national security arrangements. ${ }^{44}$

He notes later in the report that humanitarian assistance often raises difficult challenges. "Humanitarian assistance cannot stop a conflict and the diversion or abuse of humanitarian assistance may well prolong it." 45

Mrs. Ogata, in responding to the Secretary-General's Report on Africa, noted also that the "mixed nature of groups hosted in refugee camps - refugees coexisting with fighters, criminals and agents of genocide, has been the greatest challenge to the work of my Office throughout the Great Lakes crisis." 46 She comments that maintaining the civilian character of refugee camps is the responsibility of host governments. However, she notes that "different situations may require a variety of responses." She recommends a "ladder of options," in which the deployment of international police of military forces would be the "last resort."

In situations in which it may be difficult for host governments to implement the required principles, international assistance is needed in building their capacity to enforce law, for example through the provision of equipment and other logistical support for police forces... There are situations, however, in which building or supporting local capacity are inadequate to maintain the civilian character of camps. Separation of refugees from criminals can then become an important security requirement and there may be no other option but to deploy international police or military forces...I hope that the Security Council will give concrete follow-up to this recommendation and will examine the possibility - for example - to create a stand-by international force in support of humanitarian operations. ${ }^{47}$

Debate culminating in Security Council Resolution 1208 followed these reports and comments in November 1998. The Resolution states that having considered the Secretary-General's report and after affirming the primary responsibility of States hosting refugees to ensure the security, civilian and humanitarian character of refugee camps and settlements, a range of measures by the international community is needed to share the burden borne by African States hosting refugees and to support their efforts including in the areas of law enforcement, disarmament of armed elements, curtailment of the flow of arms in refugee camps and settlements, separation of refugees from other persons who donot qualify for international protection afforded to refugees... and demobilization and reintegration of former combatants. These measures could include "training, logistical and technical advice and assistance, financial support, the enhancement of national law enforcement mechanisms, the provision or supervision of security guards and the deployment in accordance with the Charter of the United Nations of international police and military forces." 48

Progress in addressing these issues was further aided through the deliberations of the Executive Committee of the High Commissioner's Programme in January 1998. This report, "The Security of Civilian and Humanitarian Character of Refugee Camps and Settlements," noted not only the problems mentioned above, but also that "insecurity can also arise as a result of several other factors, such as conflict amongst different groups within the refugee population, conflict between refugees and the local population, common crime and banditry and in certain cases, the deployment of undisciplined police and security forces. In many instances, camps are located too close to international borders. ${ }^{49}$

The report lists soft, medium, and hard options, which reflect the measures that can be taken to ensure the security and neutrality of camps. The following are some of the principal options suggested: 50

\section{Soft Options: Preventive \\ Measures and Cooperation with National Law Enforcement Authorities}

1)Location of camps: At a reasonable distance from borders;

2) Size of Camps: Not to exceed 20,000, as recommended in UNHCR's Emergency Handbook;

3) Election of refugee representatives committed to camp neutrality;

4) Distribution of aid directly to individuals and families and not through leaders;

5) Permanent presence of international humanitarian staff in or near camps;

6) Assistance to host countries to carry out refugee status determination;

7) A strategy of cooperation with national law enforcement authorities when resources of host states are overwhelmed by security problems;

8) Developing targeted training for the cooperating national forces, with a 
monitoring role over basic policing standards.

\section{Medium Options: Deployment of Civilian or Police Monitors}

1) Utilization of private security firms, direct hiring of security personnel and the deployment of civilian or police monitors (Report notes reservations about this option);

2) Deployment of multi-national civilian observers to conduct monitoring missions, which would report through Secretary-General to the Security
Council on the presence of armed elements in refugee camps;

3) Deployment of an international police force by the United Nations or by regional organizations, which could be authorized and mandated by the Security Council and comprised of police units contributed by Member States.

\section{Hard Options: Military Deployment}

Deployment of aUN Peacekeeping Operation or that of a multinational or regional force under Chapter VI or
Chapter VII. This would require the development of Stand-by arrangements of military and police units and personnel trained for humanitarian operations.

These options were expanded upon in the report of the Executive Committee of 14 September 1999, "Strengthening Partnership to Ensure Protection also in Relation to Security. ${ }^{\text {51 }}$ In reference to partnership between states, UN agencies and other actors, the report notes that "one such approach (similar to the current Danish Refugee Coun-
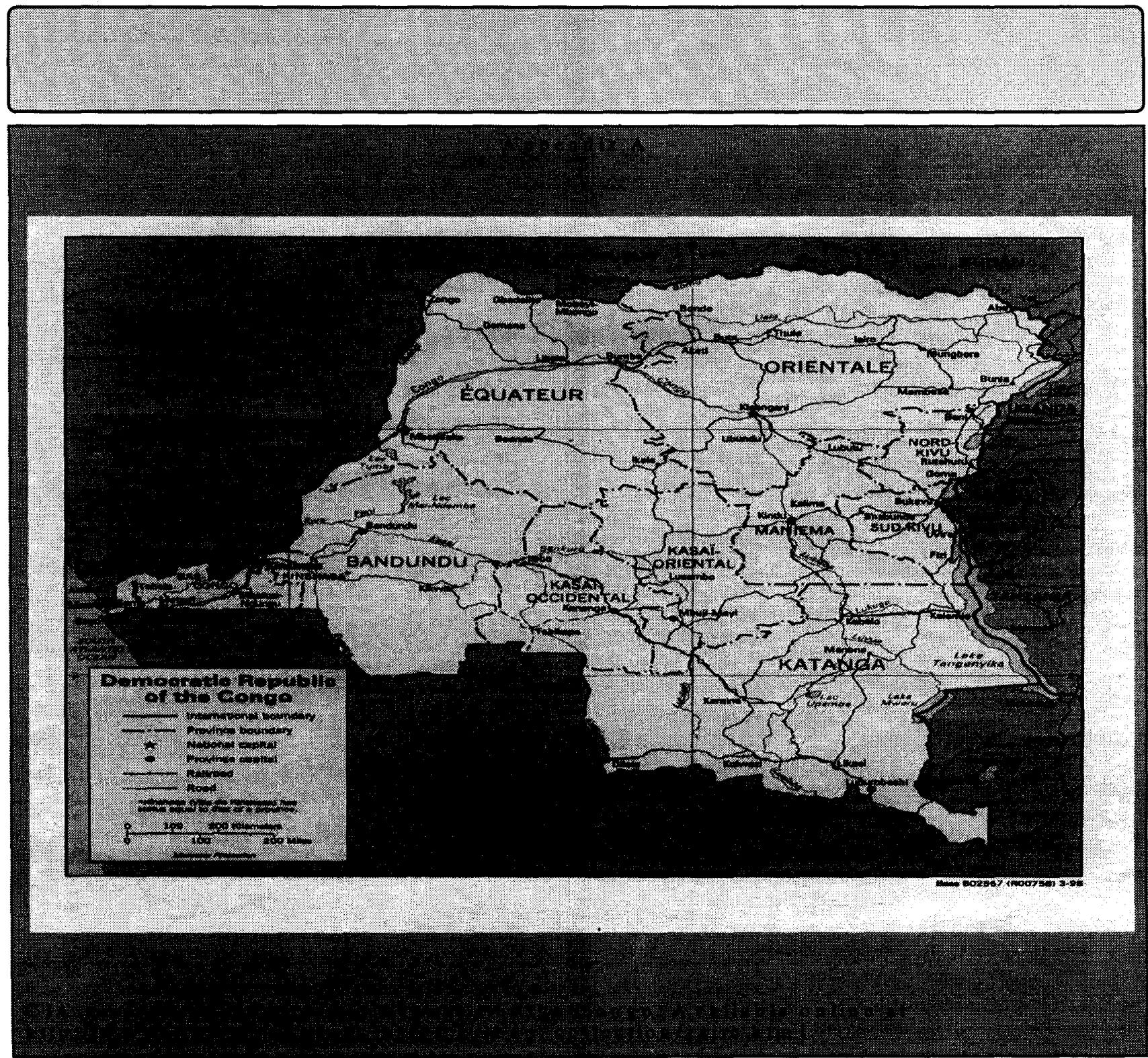
cil/Norwegian Refugee Council standby arrangement), foresees the identification of national police and/or military entities which may be rapidly deployed to provide security in camps on an emergency basis. ${ }^{52}$

In the former Yugoslav Republic of Macedonia, Swedish police officers were partners with local police to provide security in camps. Another option would be the use of stand-by arrangements such as those of the Department of Peacekeeping Operations. Yet another might be a CIVPOL model used in Bosnia and Kosovo. ${ }^{53}$

The refugee operations of UNHCR in Kosovo required close cooperation with the military. The relationship between NATO forces and UNHCR was one of the subjects examined by the UNHCR Evaluation and Policy Analysis, "The Kosovo Refugee Crisis: An Independent Evaluation of UNHCR's Emergency Preparedness and Response." 54 Security problems during this crisis prompted some criticism of UNHCR. For example, a British Parliamentary report criticized UNHCR's role on security declaring that "it is not for NATO to be involved in such work, but rather UNHCR." UNHCR responded that "for UNHCR, a central lesson of the Great Lakes experience, as of experience of the problem in other situations of unresolved conflict, is that the humanitarian organizations alone cannot, and should not, be expected to address these ssues. UNHCR itself cannot ensure that refugee camps are kept free of KLA interference, presence or control..." 55 The report noted that the presence of NATO forces in and around the camps in Northern Albania, where some guerrillas were present, provided a sense of relative security to the refugees. The ambiguity of UNHCR's position is evident in the following section 498 of the Report:

...UNHCR is willing to consider collaboration with military units in order to provide refugees with security...it is important to stress that the UNHCR Statute explicitly provides that the agency's role is supposed to be Humanitarian and non-political. ${ }^{56}$

\section{Recent Debate and Option Generation}

Much attention has been focussed on the relationship between security issues and refugee concerns, particularly since the Great Lakes crisis after 1994. The ensuing debate has generated important options for coping with the challenges of refugee security issues. ${ }^{57}$ Options involving local security forces, with the recognition that local governments often lack the capacity to deal with complex refugee emergencies, have been suggested along with options of "encadrement," or the utilization of trained and monitored cadres from the refugee community itself. The enhancement of local government security forces through bilateral or multilateral assistance might reduce dependency on the international community. CIVPOL units, typically formed of police volunteers can prevent violations of human rights by local security forces, although they are generally not equipped to deal with demilitarization programs. Private security cadres might be considered, along with international constabulary, or armed police units, to support humanitarian operations.

Presidential Decision Directive PDD 71, "Strengthening Criminal Justice Systems in Support of Peace Operations," directed theState Department to establish a new program that would train civilian police for international peacekeeping missions around the world. Civilian police would "provide a sense of security and perform tasks that heavily armed troops are not well trained to handle." 58 Although the relationship of this pool of police to humanitarian operations has yet to be spelled out, the Presidential Directive indicates a new awareness on the part of the U.S. government of the importance of these kinds of security arrangements.

\section{Conclusion}

As the twenty-first century begins, the international community confronts ever more numerous crises involving refugees. Among the most difficult is- sues challenging UNHCR are those involving security. Simply ensuring access to aid supplies can be an overwhelming task in failed states, or those engulfed in conflict. Ensuring the civilian nature of the refugee camps themselves has proved a formidable challenge, as has the necessity of providing minimum security standards within the camps in areas where host governments do not have the will or capacity to do so. Humanitarian relief workers increasingly find themselves at ground zero in violent conflicts and retaining the neutrality required by UNHCR's mandate has proven to be a delicate undertaking. Nevertheless, it is encouraging to witness the debate that has taken place since 1994, which, though not without finger pointing and scapegoating, has produced a constructive list of options for consideration. However, the most complete list of options can only be useful if it is backed by the political will of the international community to respond quickly and firmly to future crises. The challenge is whether the lessons of the past will provide wisdom for the future.

\section{Notes}

1. Helping Refugees: An Introduction to UNHCR (Geneva: UNHCR, 1998), 5.

2. For an excellent analysis of this issue, see Catherine Phuong, "UNHCR's Involvement with Internally displaced Persons: Doing Too Much or Too Little?" Unpublished paper presented at ISA Convention, 2000. See also issue of Refugees, devoted to the issue of IDP's, Vol. 4, No. 117, 1999.

3. Credit is due to Mbaidjol, Deputy Director of UNHCR's Mission to the United Nations in 1999, who introduced the author to the importance of this topic.

4. New York Times, 24 May 1994, A1: 5.

5. ibid.

6. Daniel Thurer, 'The'Failed State' and International Law," in International Review of the Red Cross, Vol. 81, No. 836, 732.

7. ibid.

8. Gil Loescher and Ann Dull Loescher, The Global Refugee Crisis: A ReferenceHandbook (Santa Barbara: ABC-CLIO, 1994), 100.

9. ibid., 133.

10. Ray Wilkinson, "Thirty Years Later," Refugees, Vol. 2, No. 115, 1999, 8. 
11. Gil Loescher and Ann Dull Loescher, op. cit., 93.

12. ibid., 96.

13. For an interesting assessment of ethnic conflict in eastern Zaire, see Capt Tim Uecker, "The Banyamulenge Struggle in Eastern Zaire: One Knot Amid a Tangle of Crises, " unpublished paper submitted for M.A. in Political Science, Rutgers University, Newark, NJ, 1997.

14. Ray Wilkinson, op. cit., 10.

15. ibid., 10.

16. "Africa's Generosity Must Continue: An Interview with President of Tanzania, Julius Nyerere." Refugees, Vol.2, No.115, 1999. 15.

17. Alain Destexhe, Op. Ed., New York Times, 9 February 1995, A 23: 1.

18. New York Times, 1 January 1995, 1, 3:3.

19. Destexhe, op. cit., 1.

20. New York Times, 16 February 1995, A 26: 5.

21. BillFrelick, "The Dangers of 'Safe Havens' for Kosovo," Refuge, Vol. 18, No. 3 (August 1999), 33.

22. Interview, March 8, 2000, Eleanor Bedford, USCommittee on Refugees. Ms. Bedford worked in Goma during the crisis.

23. Dennis McNamara, "Everyone is Found Wanting," Refugees, Vol. 110, 1997, 22.

24. For an interesting introduction to the use of mercenaries by African governments, see Steven Metz, "Refining American Strategy in Africa," INSSStudy, February 2000.

25. Interview on March 9, 2000, with Bemma Dankoh, Deputy Regional Representative of UNHCR for USA and Caribbean.

26. New York Times, 13 February 1995, A 6: 4.

27. Interview on March 9, 2000, Bemma Dankoh.

28. Refugees: Human Rights Have No Borders (New York: Amnesty International, 1997) 102.

29. For an excellent account of the 1996 crisis, see TheLost Refugees: Herded and Hunted in Eastern Zaire (Refugees International, September 1997), available online at http://www.refintl.org.
30. New York Times, 13November 1996, A1:1. See also New York Times, 14 November 1996,!, 1:3.

31. New York Times, 27 November 1996, A 12 : 1.

32. Much of this case study is based on an interview on March 9, 2000 with General James McCarthy, USAF Ret., whose area of command included Southern Turkey and Northern Iraq in 1991. In addition, see Michael N. Schmitt, "Clipped Wings: Effective and Legal No-Fly Zone Rules of Engagement," Loyola of Los Angeles International and Comparative Law Journal, Vol. 20, Dec. 1998, No. 4, 727-789.

33. S.C. Res. 688 (April 15, 1991), UN Doc.S/ RES/688 (1991).

34. The Mansfield Lecture, by Mrs. Sadako Ogata, UNHCR, Washington, D.C., 10 March 1999, available online at http:// www.unhcr.ch/refworld/unhcr/ hcspeech/990310.htm.

35. Refugees, Vol. 2, No. 112, 1998, 17.

36. Interview, March 9, 2000, Bemma Dankoh.

37. Augustine Mahiga, "A Change of Direction for Tanzania," Refugees, Vol. 119, Winter, 14.

38. See Africa Watch and Women's Rights Watch, "Seeking Refuge, Finding Terror: The Widespread Rape of Somali Women Refugees in North Eastern Kenya," Human Rights Watch Short Report, 5, No. 13 (October 1993)

39. Interview, March 9, 2000, Bemma Donkoh. 40. ibid.

41. Opening Statement by the UNHCR at the Fiftieth Session of the Executive Committee of the High Commissioner's Programme, Geneva, Monday, 4 October 1999. Available online at http:// www.unhcr.ch/refworld/unhcr/ hcspeech/991004.htm. For further information on this refugee situation, see NGO Letter to PresidentClinton, availableonline at http://www.etan.org/news/2000a/ 01ngo.htm and http:// www.amnestyusa.orgnews / 1999/ 32120666.htm.

42. "The Causes of Conflict and the Promotion of Durable Peace and Sustainable Development in Africa: Report of the Secretary General," 13 April 1998, available online at http://www.un.org/ecosocdev / geninfo/afrec/sgreport/report.htm.

43. ibid., 13.

44. ibid., 14.

45. idem. The report notes that in Liberia, over $\$ 8$ million in property, including nearly 500 vehicles, were looted from United Nations and NGO premises in April and May 1996.

46. Statement by Mrs. Sadako Ogata, UNHCR, at the Open Debate on the Secretary General's Report on the Situation in Africa, New York, 24, April, 1998.

47. ibid.

48. S/RES/1208 (1998), available online at http://www.un.org/Docs/scres/1998/ sres $1208 / \mathrm{htm}$.

49. Report of the Executive Committee of the High Commissioner's Programme, Standing Committee, 14th Meeting, 14 January 1999, "The Security and Civilian and Humanitarian Character of Refugee Camps and Settlements," available online at heep://www.unhcr/excom/standcom/ 1999 /int2.htm

50. ibid.

51. Available online at http:// www.unhcr.ch/refworld/unhcr/excom/ reports $/ 923 \mathrm{e} . \mathrm{htm}$.

52. ibid.,6.

53. ibid.

54. "The Kosovo Refugee Crisis: An Independent Evaluation of UNHCR's emergency Preparedness and Response," available online at http:// www.unhcr.ch/evaluate/kosovo/ ch6.htm

55. ibid, 10 .

56. idem.

57. These options are summarized in an informative report by Michael Dziedzic, "Protection for Humanitarian Relief Operations," INSS Study No. 168, December 1999, available online at http:// www.ndu.edu/inss.strforum / forum168.html.

58. PDD 71 of 24 February 2000 is available online at http://www.fas.org/irp/ offdocs/pdd/pdd-71.htm. a

\section{Feedback? Questions? Remarks? We welcome them all. Send to: refuge@yorku.ca}

are credited and the original publication in Refuge: Canada's Journal on Refugees is cited. 